\title{
Stratospheric ozone changes under solar geoengineering: implications for UV exposure and air quality
}

\author{
Peer Johannes Nowack $^{1}$, Nathan Luke Abraham ${ }^{1,2}$, Peter Braesicke ${ }^{3}$, and John Adrian Pyle ${ }^{1,2}$ \\ ${ }^{1}$ Centre for Atmospheric Science, Department of Chemistry, University of Cambridge, Cambridge, UK \\ ${ }^{2}$ National Centre for Atmospheric Science, University of Cambridge, Cambridge, UK \\ ${ }^{3}$ Karlsruhe Institute of Technology, IMK-ASF, 76344 Eggenstein-Leopoldshafen, Germany \\ Correspondence to: Peer Johannes Nowack (pjn35@cam.ac.uk)
}

Received: 12 October 2015 - Published in Atmos. Chem. Phys. Discuss.: 13 November 2015

Revised: 20 February 2016 - Accepted: 18 March 2016 - Published: 31 March 2016

\begin{abstract}
Various forms of geoengineering have been proposed to counter anthropogenic climate change. Methods which aim to modify the Earth's energy balance by reducing insolation are often subsumed under the term solar radiation management (SRM). Here, we present results of a standard SRM modelling experiment in which the incoming solar irradiance is reduced to offset the global mean warming induced by a quadrupling of atmospheric carbon dioxide. For the first time in an atmosphere-ocean coupled climate model, we include atmospheric composition feedbacks for this experiment. While the SRM scheme considered here could offset greenhouse gas induced global mean surface warming, it leads to important changes in atmospheric composition. We find large stratospheric ozone increases that induce significant reductions in surface UV-B irradiance, which would have implications for vitamin $\mathrm{D}$ production. In addition, the higher stratospheric ozone levels lead to decreased ozone photolysis in the troposphere. In combination with lower atmospheric specific humidity under SRM, this results in overall surface ozone concentration increases in the idealized G1 experiment. Both UV-B and surface ozone changes are important for human health. We therefore highlight that both stratospheric and tropospheric ozone changes must be considered in the assessment of any SRM scheme, due to their important roles in regulating UV exposure and air quality.
\end{abstract}

\section{Introduction}

The scientific consensus (Stocker et al., 2013) is that manmade climate change caused by anthropogenic emissions of greenhouse gases such as carbon dioxide is taking place. It is recognized that reducing greenhouse gas emissions is difficult so that, under these circumstances, there is discussion on alternative measures to counteract the effects of climate change (e.g. Govindasamy and Caldeira, 2000; Cicerone, 2006; Crutzen, 2006). Such interventions are commonly referred to as geoengineering, "the intentional large-scale manipulation of the environment that is intended to reduce undesired anthropogenic climate change" (Keith, 2000).

Here, we use an atmosphere-ocean chemistry-climate model to study atmospheric composition changes for one of the most common geoengineering modelling experiments: the reflection of solar energy before it can enter the Earth's atmosphere, an idea often depicted by the use of space mirrors (Early, 1989; Seifritz, 1989). This idealized geoengineering experiment belongs to methods subsumed under the term solar radiation management (SRM). SRM methods aim to offset the additional radiative forcing due to increases in atmospheric greenhouse gas concentrations by reflecting solar radiation before it can reach the Earth's surface. A major issue with any SRM scheme is that they are not designed to directly address the cause of change, namely the elevated levels of carbon dioxide and other greenhouse gases in the Earth system. Instead they affect other processes whose changes counteract those due to the greenhouse gases (Shepherd, 2009). This has been demonstrated in numerous SRM modelling studies (e.g. Govindasamy and Caldeira, 2000; 
Govindasamy et al., 2002, 2003; Bala et al., 2008; Jones et al., 2011; Kravitz et al., 2012, 2013b; Lunt et al., 2008; Matthews and Caldeira, 2007; Niemeier et al., 2013; Ricke et al., 2010; Robock et al., 2008; Schmidt et al., 2012; Tilmes et al., 2013).

Atmospheric composition changes under SRM have received much attention in the context of stratospheric particle injection schemes (Budyko, 1977; Crutzen, 2006) as increased particle loadings could enhance the heterogeneous catalysis of reactions that eventually lead to ozone depletion (e.g. Heckendorn et al., 2011; Pitari et al., 2014; Pope et al., 2012; Rasch et al., 2008; Tilmes et al., 2008, 2009, 2012; Weisenstein and Keith, 2015). This would have important implications for human health since stratospheric ozone is the major absorber of solar UV-B radiation. UV-B radiation interacts with the human DNA and has been connected to many acute and chronic illnesses of the eye, immune system, and skin and, inter alia, to various forms of skin cancer (e.g. Norval et al., 2011; Slaper et al., 1996).

However, UV-B radiation is also needed in beneficial biological processes such as in the photobiological production of vitamin D (Holick, 1981). Consequently, a large future increase in the total column amount of ozone, and thus decreased surface UV-B radiation, could itself have severe adverse effects on life on Earth (McKenzie et al., 2009). Vitamin D deficiency, for example, has been related to an increased likelihood of occurrence of internal cancers, autoimmune diseases, mental illnesses and lower bone density (e.g. Mora et al., 2008; Norval et al., 2011; Ross et al., 2011; Williamson et al., 2014). Other organisms in the biosphere also depend on UV radiation including certain types of plants whose defence mechanisms against pests and pathogenic micro-organisms are regulated by UV-B radiation (Williamson et al., 2014).

Surface ozone is a pollutant, which has been associated both with diseases of the respiratory system and crop damage (Avnery et al., 2011; Silva et al., 2013). Many countries have introduced emission controls aimed at reducing emissions of tropospheric ozone precursors. However, tropospheric surface ozone depends not just on in situ emissions but also on processes in the stratosphere. For example, changes in stratospheric ozone will impact tropospheric chemistry by altering the photolysis environment in the troposphere (Madronich et al., 2015). Similarly, the transport of ozone from the stratosphere is an important component of the tropospheric ozone budget (e.g. Holton et al., 1995; Neu et al., 2014). Any SRM scheme which affects the stratosphere could therefore also impact tropospheric composition.

In contrast to the case of particle injection schemes, stratospheric composition changes and their potential tropospheric impacts in a "space-mirror" geoengineered climate have not yet been included in a 3D atmosphere-ocean modelling study. We investigate changes in ozone, and consequently in biologically active ultraviolet surface radiation (in particular UV-B), contrasting our results with composition changes un- der pure greenhouse gas forcing. Changes in UV-B fluxes by changes in clouds and surface albedo are also considered. Finally, we briefly discuss potential surface ozone, and thus air quality changes as a result of SRM.

This paper is organized as follows: Sects. 2.1 and 2.2 introduce the model used to run the simulations and the experimental setup. Section 3.1 introduces the global and regional surface temperature response. Changes in atmospheric composition and their impact on surface UV and air quality are explained in Sects. 3.2. to 3.4. Finally, Sect. 4 puts our results into context, also regarding other SRM schemes and health implications.

\section{Experimental setup}

\subsection{Model description}

A version of the recently developed atmosphere-ocean coupled configuration of the Hadley Centre Global Environment Model version 3, additionally coupled to an atmospheric chemistry scheme, has been employed here (Hewitt et al., 2011; Nowack et al., 2015).

For the atmosphere, the UK Met Office's Unified Model (MetUM) version 7.3 is used (Hewitt et al., 2011). The configuration is based on a regular grid with a horizontal resolution of $3.75^{\circ}$ longitude by $2.5^{\circ}$ latitude and comprises 60 vertical levels up to a height of $\sim 84 \mathrm{~km}$, and so includes a full representation of the stratosphere. Its dynamical core is non-hydrostatic and employs a semi-Lagrangian advection scheme. The radiation scheme by Edwards and Slingo (1996) is used in the MetUM, with nine bands in the longwave and six bands in the shortwave part of the spectrum, extended by the $k$ distribution method by Cusack (1999). Subgridscale features such as clouds and gravity waves are parameterized.

For ocean dynamics and thermodynamics an updated version of the OPA component (Hewitt et al., 2011; Madec et al., 1998) of the Nucleus for European Modelling of the Ocean (NEMO) framework version 3.0, coupled to the Los Alamos sea ice model CICE version 4.0 (Hunke and Lipscomb, 2008) is used. It contains 31 vertical levels reaching down to a depth of $5 \mathrm{~km}$. The NEMO configuration used in this study deploys a tripolar, locally anisotropic grid which has $2^{\circ}$ resolution in longitude everywhere, but an increased latitudinal resolution in certain regions with up to $0.5^{\circ}$ in the tropics.

Atmospheric chemistry is represented by the United Kingdom Chemistry and Aerosols (UKCA) model in an updated version of the stratospheric chemistry configuration (Morgenstern et al., 2009) which is coupled to the MetUM. The stratospheric chemistry scheme is comprehensive. A relatively simple tropospheric chemistry scheme that simulates hydrocarbon oxidation is also included, which provides for emissions of three chemical species (NO (surface, lightning), $\mathrm{CO}$ (surface), $\mathrm{HCHO}$ (surface)). In addition, surface mixing 
Table 1. Overview of the simulations.

\begin{tabular}{lrc}
\hline Run & $\begin{array}{r}\text { Carbon } \\
\text { dioxide } \\
(\mathrm{ppmv})\end{array}$ & $\begin{array}{c}\text { Solar constant } \\
\text { reduction }\left(\mathrm{Wm}^{-2}\right)\end{array}$ \\
\hline piControl & 285 & - \\
$4 \times \mathrm{CO}_{2}$ & 1140 & - \\
$\mathrm{G} 1$ & 1140 & 49.0 \\
\hline
\end{tabular}

ratios of four further species $\left(\mathrm{N}_{2} \mathrm{O}, \mathrm{CH}_{3} \mathrm{Br}, \mathrm{H}_{2}, \mathrm{CH}_{4}\right)$ are constrained by calculating the effective emission required to maintain their surface mixing ratios, e.g. for nitrous oxide $280 \mathrm{ppbv}$ and for methane $790 \mathrm{ppbv}$. This keeps their tropospheric mixing ratios approximately constant at preindustrial levels in all simulations. Nitrogen oxide emissions from lightning are parameterized according to Price and Rind (1992, 1994). Ozone, nitrous oxide, and methane are fully interactive in the model so that any changes in these species are seen by the radiation module and thus affect the modelled climate. Changes in photolysis rates in the troposphere and the stratosphere are calculated interactively using the Fast-JX photolysis scheme (Bian and Prather, 2002; Neu et al., 2007; Telford et al., 2013; Wild et al., 2000). Photolysis in FastJX responds, inter alia, to ozone and solar flux as well as to multiple layers of clouds of varying degrees of thickness.

\subsection{The simulations - the GeoMIP G1 experiment}

Our simulations follow standards set for the G1 experiment (see Table 1), which was defined as part of the Geoengineering Model Intercomparison Project (GeoMIP) (Kravitz et al., 2011, 2013a). In the G1 experiment the effect of an abrupt quadrupling of atmospheric carbon dioxide $\left(\mathrm{CO}_{2}\right)$ on the global mean surface temperature is approximately offset by reducing the model's solar constant. This can be thought of as an experiment in which space-mirrors reflect sunlight before it enters the Earth's atmosphere (Early, 1989; Seifritz, 1989). Starting from approximately pre-industrial concentrations with atmospheric $\mathrm{CO}_{2}$ at $\sim 285 \mathrm{ppmv}$ (piControl), we thus carried out, firstly, an abrupt $4 \times \mathrm{CO}_{2}$ experiment, in which atmospheric $\mathrm{CO}_{2}$ is instantaneously quadrupled to $\sim 1140$ ppmv and, secondly, a G1 type experiment in which the global warming caused by $4 \times \mathrm{CO}_{2}$ was offset by a solar irradiance reduction of $49.0 \mathrm{Wm}^{-2}(\sim 3.6 \%)$. This value lies well within the range found in previous G1 modelling studies (e.g. Schmidt et al., 2012). It was obtained by iterating the radiative imbalance at the top of the atmosphere and the global mean surface temperature response to various values of solar dimming, thereby optimizing the latter towards a zero offset from the pre-industrial simulation. The radiative forcing in the $4 \times \mathrm{CO}_{2}$ experiment roughly matches the levels attained by the end of the 21 st century under the transient RCP8.5 forcing scenario defined for the Coupled Model In-

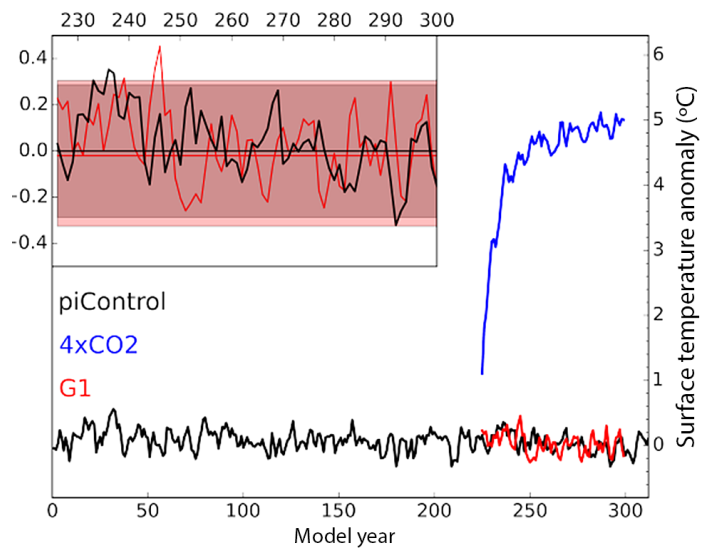

Figure 1. Temporal evolution of the annual and global mean surface temperature anomalies. The anomalies $\left({ }^{\circ} \mathrm{C}\right)$ are shown relative to the average temperature of the pre-industrial experiment. The piControl and G1 experiment are highlighted in the inset panel with the straight lines marking the average temperature anomalies. The grey and red shading give the $\pm 2 \sigma$ temperature interval for piControl and G1 respectively.

tercomparison Project phase 5 (Moss et al., 2010; Taylor et al., 2012). Both experiments were run for 75 years after the $\mathrm{CO}_{2}$ and solar forcings were imposed. For analysis, we use the last 50 years of each experiment in the following. By design, the G1 experimental set-up does not include pre-defined changes in surface emissions of ozone-depleting substances from anthropogenic sources (e.g. CFCs whose abundance is equal to zero in this set-up), or tropospheric ozone precursors.

The highly idealized nature and theoretical simplicity of the $\mathrm{G} 1$ experiment allows us to discuss possible unintended consequences of solar geoengineering in an intuitive way. Our stratospheric chemistry scheme allows a detailed analysis of possible changes in UV penetration into the troposphere as well as of stratosphere-troposphere exchange of ozone. Our tropospheric chemistry scheme, while simplified, then allows a simple, first-order quantification of the impact of these on tropospheric composition. While the exact impact of any changes would be strongly dependent on both forcing scenario and SRM scheme, this study aims to demonstrate why changes in these metrics are to be expected for any SRM scheme.

\section{Results}

\subsection{Surface temperature response}

The temporal evolution of the global mean surface temperature for all simulations is shown in Fig. 1. As expected, a rapid warming is found in $4 \times \mathrm{CO}_{2}$ relative to piControl in response to the abrupt forcing whereas G1 remains (by design) at effectively the same average surface temperature (Table 2). 

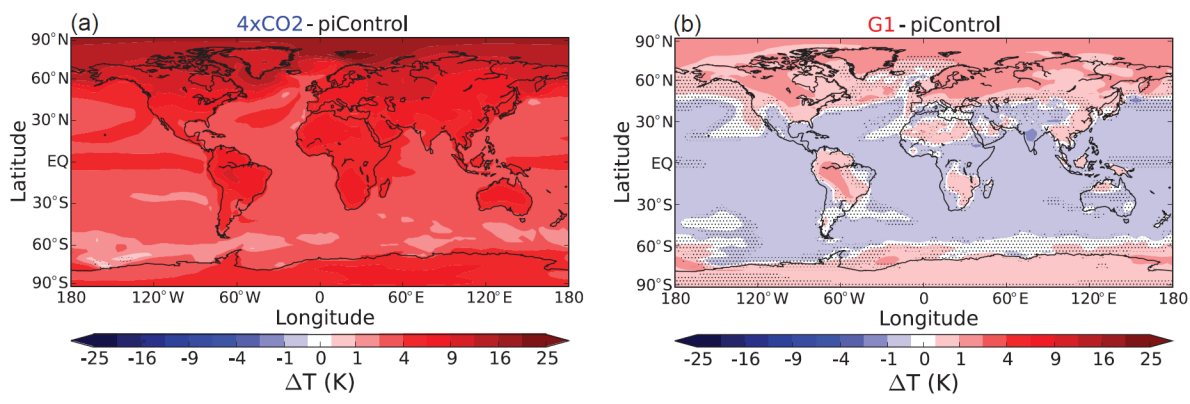

Figure 2. Annual mean surface temperature differences. The differences are based on the average temperatures of the last 50 years of each experiment. (a) $4 \times \mathrm{CO}_{2}$ relative to preindustrial conditions. (b) G1 relative to pre-industrial conditions. Note the non-linear colour scale. Non-significant changes (using a two-tailed Student's $t$ test at the $95 \%$ confidence level) are marked by stippling.

Although surface temperatures are offset globally, there are important regional differences between $4 \times \mathrm{CO}_{2}$ and $\mathrm{G} 1$. As shown in Fig. 2, the model yields the characteristic distribution of overcooling in the tropics and warming at high latitudes in G1 (Kravitz et al., 2013b), an effect which can be explained by the proportionally larger impact of reducing insolation on the tropics than on high latitudes (Govindasamy and Caldeira, 2000; Lunt et al., 2008).

\subsection{Stratospheric ozone and temperature changes}

Figure 3a to d show latitude-height cross sections of changes in zonal mean ozone mass mixing ratio and zonal mean temperature. We find large increases in ozone in the middleupper stratosphere ( $\sim 30-50 \mathrm{~km}$ altitude, Fig. 3a and b) under both $4 \times \mathrm{CO}_{2}$ and G1, a ubiquitous feature in chemistryclimate modelling studies (e.g. Oman et al., 2010) with a cooler stratosphere (Fig. 3c) under increased atmospheric $\mathrm{CO}_{2}$ concentrations (Fels et al., 1980). Note that this cooling effect largely persists in $\mathrm{G} 1$; the stratosphere is warmer in some areas than in $4 \times \mathrm{CO}_{2}$, but remains much colder than in piControl (compare Fig. $3 \mathrm{c}$ and d). $\mathrm{CO}_{2}$-driven ozone increases in the middle-upper stratosphere are well understood and are mainly caused by a slowing of temperaturedependent catalytic ozone $\left(\mathrm{O}_{3}\right)$ loss reactions

$\mathrm{X}+\mathrm{O}_{3} \rightarrow \mathrm{XO}+\mathrm{O}_{2}$

$\mathrm{XO}+\mathrm{O} \rightarrow \mathrm{X}+\mathrm{O}_{2}$

Net: $\mathrm{O}+\mathrm{O}_{3} \rightarrow 2 \mathrm{O}_{2}$

under cooler stratospheric conditions (Haigh and Pyle, 1982), with the radical species $X$ typically being NO, OH, $\mathrm{Cl}$ or $\mathrm{Br}$. The cooling also shifts the thermal partitioning between atomic oxygen and ozone towards the latter, which further slows down the rate-determining step (Reaction R2) in the catalytic cycles (Jonsson et al., 2004). As already mentioned, the stratospheric cooling due to increased $\mathrm{CO}_{2}$ persists in G1. In fact, the solar irradiance reduction would, as a single effect, be expected to further cool the stratosphere (Govindasamy et al., 2003; Braesicke et al., 2011). However, some regions in the stratosphere are actually warmer in $\mathrm{G} 1$ than in $4 \times \mathrm{CO}_{2}$ (Fig. 3d). Increased shortwave heating by higher ozone levels, local tropopause height shifts, and changes in dynamical heating certainly contribute to this, and importantly so does less longwave cooling as a result of the much lower stratospheric water vapour concentrations (Maycock et al., 2011) in G1, as discussed below.

The ozone increases in the upper stratosphere are larger in $\mathrm{G} 1$ than under $4 \times \mathrm{CO}_{2}$ (compare Fig. 3a and b), see also Jackman and Fleming (2014). In our simulations, there are two main drivers behind this additional ozone increase. Firstly, less ozone is photolysed $\left(\mathrm{O}_{3}+h v->\mathrm{O}_{2}+\mathrm{O}\right)$ as a consequence of the reduced insolation in $\mathrm{G} 1$, which happens at the expense of atomic oxygen abundances: in G1 both ground state $\mathrm{O}\left({ }^{3} \mathrm{P}\right)$ and excited state $\mathrm{O}\left({ }^{1} \mathrm{D}\right)$ at a given atmospheric pressure are $\sim 3-8 \%$ less abundant than in $4 \times \mathrm{CO}_{2}$ (not shown). Less abundant atomic oxygen in turn implies a slowing of Reaction (R2) and thus further reduced ozone loss. Secondly, we find a significant decrease in stratospheric specific humidity in $\mathrm{G} 1$, which reduces $\mathrm{HO}_{x}\left(\mathrm{OH}, \mathrm{HO}_{2}, \mathrm{H}\right)$ formation and therefore ozone loss via, for example, Reactions (R1) and (R2). Specifically, the stratosphere is $\sim 10$ $20 \%$ drier in G1 than in piControl. This is related to a weaker hydrological cycle under SRM (e.g. Bala et al., 2008; Govindasamy et al., 2003; Kravitz et al., 2013b; Lunt et al., 2008; Matthews and Caldeira, 2007; Ricke et al., 2010; Schmidt et al., 2012; Tilmes et al., 2009, 2013), which gives rise to characteristic reductions in global mean precipitation (Table 2) and evaporation. In contrast, the more humid stratosphere found under $4 \times \mathrm{CO}_{2}(\sim 30 \%$ wetter than pre-industrial) results in greater production of $\mathrm{HO}_{x}$ species, which is additionally coupled to the above-mentioned changes in $\mathrm{O}\left({ }^{1} \mathrm{D}\right)$ via the $\mathrm{HO}_{x}$-producing reaction $\mathrm{H}_{2} \mathrm{O}+\mathrm{O}\left({ }^{1} \mathrm{D}\right)->2 \mathrm{OH}$. As $\mathrm{O}\left({ }^{1} \mathrm{D}\right)$ concentrations are lower in $\mathrm{G} 1$ than in $4 \times \mathrm{CO}_{2}$, this further enhances the differences in $\mathrm{HO}_{x}$; overall the abundance of $\mathrm{OH}$ and $\mathrm{HO}_{2}$ is $\sim 15-25 \%$ smaller in the middleupper stratosphere in G1. Finally, higher levels of nitrogen oxides $\left(\mathrm{NO}_{x}=\mathrm{NO}, \mathrm{NO}_{2} ; \sim, 5-13 \%\right)$ in the upper stratosphere under $4 \times \mathrm{CO}_{2}$ will also contribute to the differences in ozone. They are mainly driven by changes in stratospheric temperature, photolysis, transport of the $\mathrm{NO}_{x}$ precursor ni- 

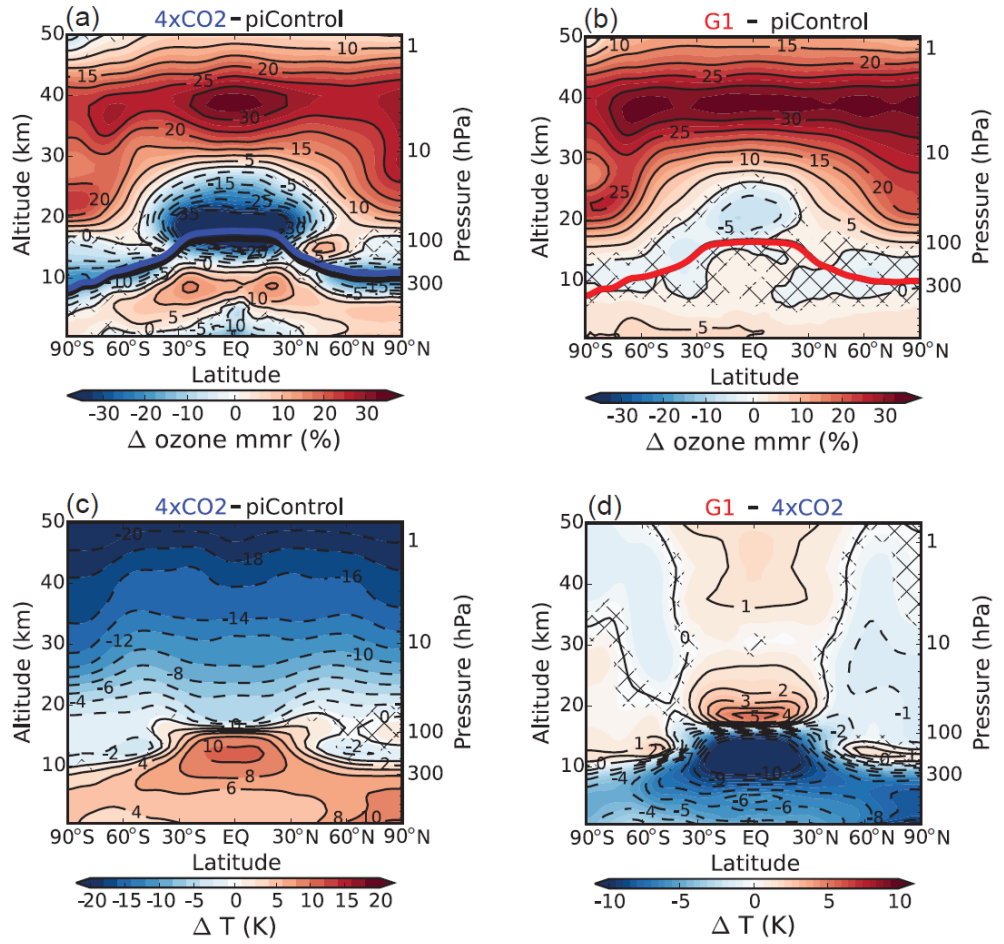

Figure 3. Differences in zonal and annual mean ozone mass mixing ratio and temperature. (a, b) Percentage differences in ozone as labelled. (c, d) Temperature differences $(\mathrm{K})$ as labelled. Note that (d) shows the difference between $\mathrm{G} 1$ and $4 \times \mathrm{CO}_{2}$, i.e. not the changes relative to piControl, in contrast to (a)-(c), and that a different colour scale is used than in (c). The ozone changes are given in percentages to highlight in terms of absolute mass mixing ratios the much smaller changes in the ozone-poor troposphere as compared to the larger absolute changes in the stratosphere, which in turn occur on much higher background ozone levels. The colour scale for ozone is adapted to changes in the middle-upper stratosphere; for the whole extent of the changes in the tropical upper troposphere and lower stratosphere under $4 \times \mathrm{CO}_{2}$, see Nowack et al. (2015). Differences are calculated on altitude levels, the pressure axis gives approximate values for pre-industrial conditions. Coloured lines in $(\mathbf{a}, \mathbf{b})$ mark the zonal and annual mean tropopause heights for each experiment. Non-significant differences (using a two-tailed Student's $t$ test at the $95 \%$ confidence level) are crossed out.

Table 2. Global annual mean quantities. For piControl and corresponding differences under $4 \times \mathrm{CO}_{2}$ and $\mathrm{G} 1$ (highlighted in bold). The clear-sky, unpolluted UV index at noon is calculated using the formula by Madronich (2007), including only changes by column ozone and by the solar irradiance reduction. Standard deviations for the annual mean data are given in brackets, with the exception of the mean UVI indices, which were calculated from climatological ozone fields without inter-annual variation.

\begin{tabular}{|c|c|c|c|}
\hline & piControl & $4 \times \mathrm{CO}_{2}$ & G1 \\
\hline Surface temperature $(\mathrm{K})$ & $288.27(0.13)$ & $+4.80(0.16)$ & $-\mathbf{0 . 0 2}(0.14)$ \\
\hline Precipitation $\left(\mathrm{mm}\right.$, day $\left.^{-1}\right)$ & $\mathbf{3 . 0 9}(0.01)$ & $+\mathbf{0 . 1 9}(0.01)$ & $-\mathbf{0 . 1 5}(0.01)$ \\
\hline Surface ozone vmr (ppbv) & $12.0(0.01)$ & $-0.5(0.1)$ & $+\mathbf{0 . 6}(0.1)$ \\
\hline $\mathrm{STE} \mathrm{O}_{3}\left(\mathrm{Tg} \mathrm{yr}^{-1}\right)$ & $456(22)$ & $+172(27)$ & $-7(21)$ \\
\hline Column ozone (DU) & $305.7(1.2)$ & $+\mathbf{1 2 . 9}(1.7)$ & $+23.6(1.6)$ \\
\hline UV index & 7.93 & -0.07 & -0.79 \\
\hline
\end{tabular}

trous oxide as well as its reaction with $\mathrm{O}\left({ }^{1} \mathrm{D}\right)$; a discussion of various factors involved is for example given in Revell et al. (2012). Changes in other radical species play secondary roles in this experiment (Jackman and Fleming, 2014).
In the tropical lower stratosphere, we find ozone decreases under $4 \times \mathrm{CO}_{2}$, which is characteristic for an acceleration of the Brewer-Dobson circulation under $\mathrm{CO}_{2}$-driven tropospheric warming (Shepherd and McLandress, 2011; Nowack et al., 2015). In response to solar geoengineering, the residual circulation (not shown) and thus ozone (Fig. 3b) in the tropical lower stratosphere is almost brought back to preindustrial levels. The remaining ozone decreases mainly result from an effect often referred to as "inverse self-healing" of the ozone column (e.g. Haigh and Pyle, 1982; Jonsson et al., 2004; Portmann and Solomon, 2007), in which the increased ozone concentrations in the upper stratosphere allow less shortwave radiation to propagate to lower altitudes. Relative to pre-industrial conditions, this mechanism acts in concert with the (by design) reduced insolation to leave fewer photons of relevant wavelengths to produce ozone in the lower stratosphere. However, these effects are partly compensated by coincident decreases in ozone losses in G1, mainly due to the lower temperatures and lower $\mathrm{HO}_{x}$ concentrations than in piControl. Overall, the significant changes in stratospheric ozone have important implications for UV 
fluxes into the troposphere and to the surface, as discussed in Sects. 3.3 and 3.4 .

\subsection{The effect of column ozone and cloud changes on surface UV-B}

UV-B surface fluxes can change for a variety of reasons (Bais et al., 2015; McKenzie et al., 2011). Changes in column ozone have the potential to provide particularly strong contributions since ozone is the only major absorber of UV-B radiation in the atmosphere. As discussed above, SRM could lead to changes in column ozone; in G1, we find that relative to piControl the global mean column ozone increased by $\sim 8 \%$ compared to only $\sim 4 \%$ under $4 \times \mathrm{CO}_{2}$ (Fig. 4 and Table 2).

The harmful effect of UV exposure on human skin is commonly measured using the UV index (UVI), starting at 0 and with higher UVI equalling greater skin-damaging potential (WHO, 2002). Here, we use the approximate formula of Madronich (2007) to estimate UVI changes in response to the changes in column ozone in $4 \times \mathrm{CO}_{2}$ and $\mathrm{G} 1$ under clear-sky, unpolluted conditions:

$\mathrm{UVI} \sim 12.5 \mu^{2.42}(\Omega / 300)^{-1.23}$,

where $\mu$ is the cosine of the solar zenith angle and $\Omega$ the total vertical ozone column in Dobson Units (DU). As a further approximation, we use monthly and zonal mean values for column ozone, but have updated the solar zenith angle on a daily basis according to the changing solar declination. The resulting UVI is therefore both a function of the changing angle of incidence of the Sun's radiation to the Earth's surface and the seasonally varying column ozone (Fig. $4 \mathrm{c}$ and d) at a given location. The UVI found for piControl at noon and relative changes $(\triangle \mathrm{UVI})$ for $\mathrm{G} 1$ and $4 \times \mathrm{CO}_{2}$ in percentages, are shown in Fig. $4 \mathrm{e}$ and $\mathrm{f}$ (see Table 2 for global mean differences). In G1, the UVI decreases everywhere during the whole year due to both changes in column ozone and the $3.6 \%$ reduced intensity of the solar radiation. However, the effect of the changes in ozone generally dominates. In particular, during Northern Hemisphere $(\mathrm{NH})$ spring and summer average decreases of $10-20 \%$ are found at $\mathrm{NH}$ mid- and high latitudes in G1. We caution that although the percentage changes at high latitudes may be larger, they are relative to much lower background UVI levels. In addition, Eq. (1) is expected to perform less well in areas of high surface albedo, as well as in regions with widespread occurrences of sea and land ice (Madronich, 2007). Nevertheless, a further reduction in UV irradiance in already light-poor seasons and regions could aggravate medical conditions connected to vitamin D deficiency. We note that vitamin D production exhibits a slightly different sensitivity to certain wavelengths of solar radiation than is assumed in the calculation of the UVI (Fioletov et al., 2009; McKenzie et al., 2009) so that our calculations should be considered as qualitative.
Column ozone changes are not the only factor with the potential to change surface UV as a result of climate engineering. Changes in clouds, surface reflectivity (due to surface albedo changes), or aerosols could all significantly affect UV transmission, reflection, and scattering. Here, we focus just on the impact of ozone and cloud changes, assuming that other changes are small under pre-industrial background conditions. The residual high-latitude warming in G1 (Fig. 2b) implies that albedo changes could play a role, e.g. due to decreases in snow and sea ice. However, in our model, the higher temperatures do not suffice to trigger statistically significant ice or snow loss under SRM, in agreement with multi-model studies of the G1 experiment (Kravitz et al., 2013b; Moore et al., 2014).

A common way to estimate the average effect of clouds on shortwave ( $\mathrm{SW}$ ) surface radiation is the cloud modification factor $\left(\mathrm{CMF}_{\mathrm{SW}}\right)$. The $\mathrm{CMF}_{\mathrm{SW}}$ is the total solar irradiance $\left(\mathrm{Wm}^{-2}\right)$ reaching the Earth's surface at any point (allsky) divided by its idealized clear-sky value in which any cloud effects are ignored (den Outer et al., 2005). A CMF of 1 thus implies that the net cloud effect on surface SW radiation is zero, values larger than 1 imply SW amplification by clouds, values smaller than 1 net reflection of SW radiation by clouds. Figure $5 \mathrm{a}$ and $\mathrm{b}$ show differences in the $\mathrm{CMF}_{\mathrm{SW}}$ for $4 \times \mathrm{CO}_{2}$ and $\mathrm{G} 1$ relative to piControl. Under $4 \times \mathrm{CO}_{2}$, the overall pattern of $\mathrm{CMF}_{\mathrm{SW}}$ changes is in agreement with previous (chemistry-)climate modelling results (Bais et al., 2011, 2015) under greenhouse gas forcing. In $\mathrm{G} 1$ (Fig. 5b), the $\mathrm{CMF}_{\mathrm{SW}}$ is predicted to increase in many regions while decreases are virtually non-existent. Similar cloud changes have been found in previous G1 modelling studies and have been attributed to reductions in the highly reflective cloud cover at low altitudes (Kravitz et al., 2013b; Schmidt et al., 2012). Consequently, an increase in surface SW radiation from cloud changes is expected in G1, in contrast to the decrease in UVI which would follow the column ozone changes.

In order to compare the UV effects of changes in the $\mathrm{CMF}_{\mathrm{SW}}$ and changes in ozone, we use an empirical relationship established by den Outer et al. (2005) and modified by Staiger et al. (2008) to estimate the effect of the $\mathrm{CMF}_{\mathrm{SW}}$ changes in terms of the UVI at noon. The results are presented in Fig. 5c and d. In G1, the UVI changes by clouds are overall positive. As expected, this is the opposite sign response to the UVI changes induced by ozone. However, the cloud effect is much smaller with percentage increases of only $\sim 1-2 \%$ for most latitudes and times compared with the much higher values for the ozone-induced changes (Fig. 4f). Only during NH summer, between around $40-60^{\circ} \mathrm{N}$, are the cloud-induced UVI increases of comparable size $(\sim 5 \%)$ to the decreases driven by changes in the ozone column. Our calculations show that cloud effects are generally small and do not offset ozone-induced UV changes in light-poor seasons, which are the times when major problems connected to vitamin D deficiency primarily occur. 

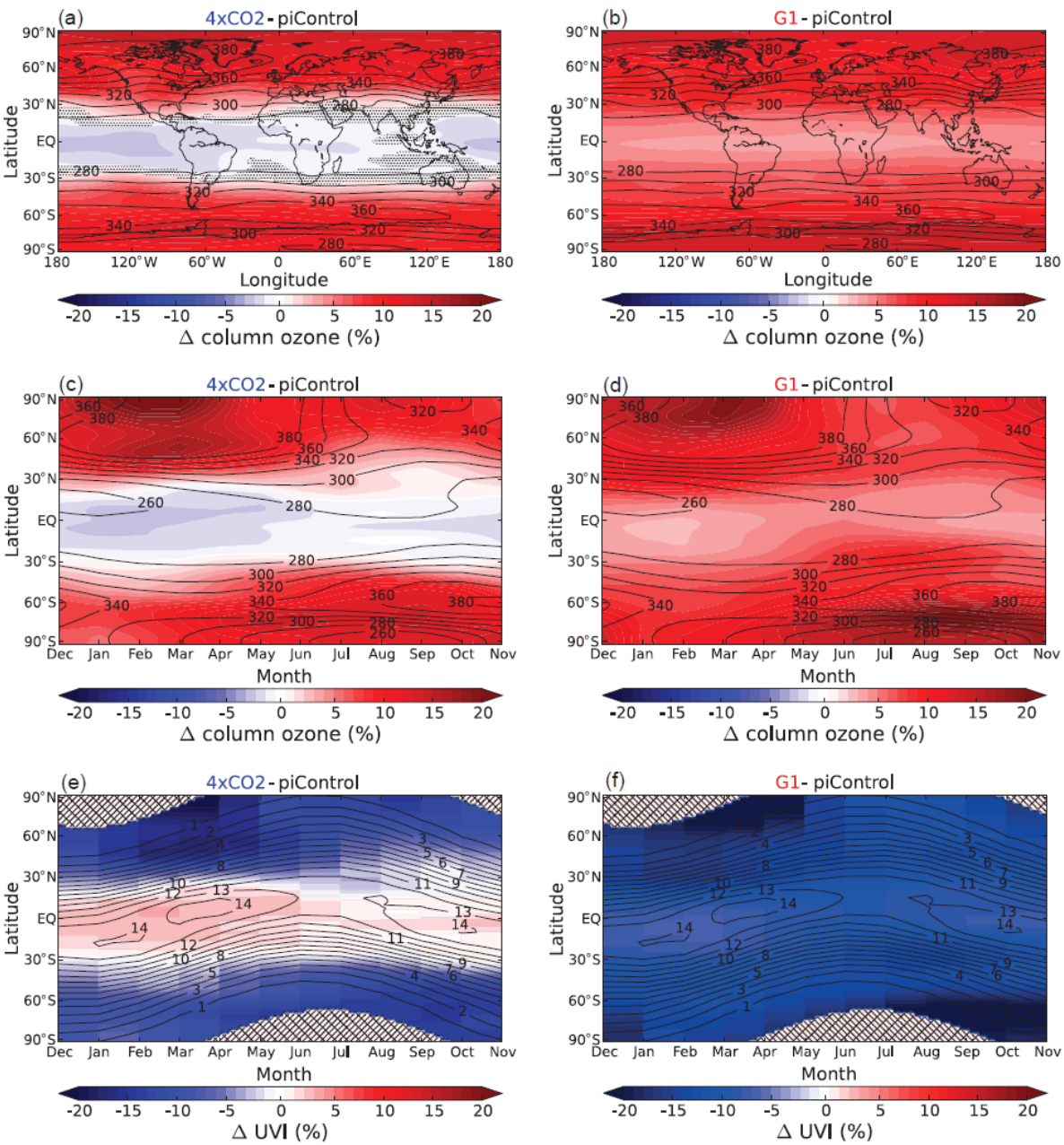

Figure 4. Column ozone differences and their impact on the UV index. Relative to piControl: left for $4 \times \mathrm{CO}_{2}$, right for $\mathrm{G} 1$. Top row panels: annual mean $\Delta$ column ozone (colours, \%). Non-significant changes (using a two-tailed Student's $t$ test at the $95 \%$ confidence level) are marked by stippling. Middle row panels: seasonal cycle of the column ozone changes as longitudinal and monthly means. Bottom row panels: seasonal cycle of the column ozone induced changes in the UV index, and in (f) additionally by the solar constant reduction, at noon. Polar night regions in (e, f) are crossed out; both daily (solar declination) and monthly changes (ozone) are considered, giving rise to a less smooth appearance. Contour lines show pre-industrial column ozone in Dobson Units (DU) in the upper two rows and pre-industrial UV indices in the last row.

In summary, our results indicate that changes in column ozone and hence surface UV fluxes represent an important change to the climate system, which could arise following an SRM scheme and which is of potential importance for human health. These changes would need to be taken into account when evaluating benefits and risks of any possible geoengineering scheme in which elevated atmospheric $\mathrm{CO}_{2}$ concentrations persist.

\subsection{Tropospheric ozone changes}

As mentioned in Sect. 1, tropospheric ozone affects air quality, human health, and ecology. Ozone concentrations in the troposphere are controlled by a variety of processes which could be affected by SRM. These include i. Photochemical processes influenced by changing UV-B $280-315 \mathrm{~nm})$ and UV-A $(315-400 \mathrm{~nm})$ fluxes into the troposphere (Madronich et al., 2015; Williamson et al., 2014). High-energy photons needed to produce ozone from molecular oxygen $(\lambda<240 \mathrm{~nm})$ are absorbed at higher altitudes and tropospheric ozone levels are determined by other production and loss processes. For example, under clean environmental background conditions, ozone loss and production of the hydroxyl radical $\mathrm{OH}$ via

$$
\begin{aligned}
& \mathrm{O}_{3}+h v(\lambda<328 \mathrm{~nm}) \rightarrow \mathrm{O}_{2}+\mathrm{O}\left({ }^{1} \mathrm{D}\right) \\
& \mathrm{O}\left({ }^{1} \mathrm{D}\right)+\mathrm{H}_{2} \mathrm{O} \rightarrow 2 \mathrm{OH}
\end{aligned}
$$



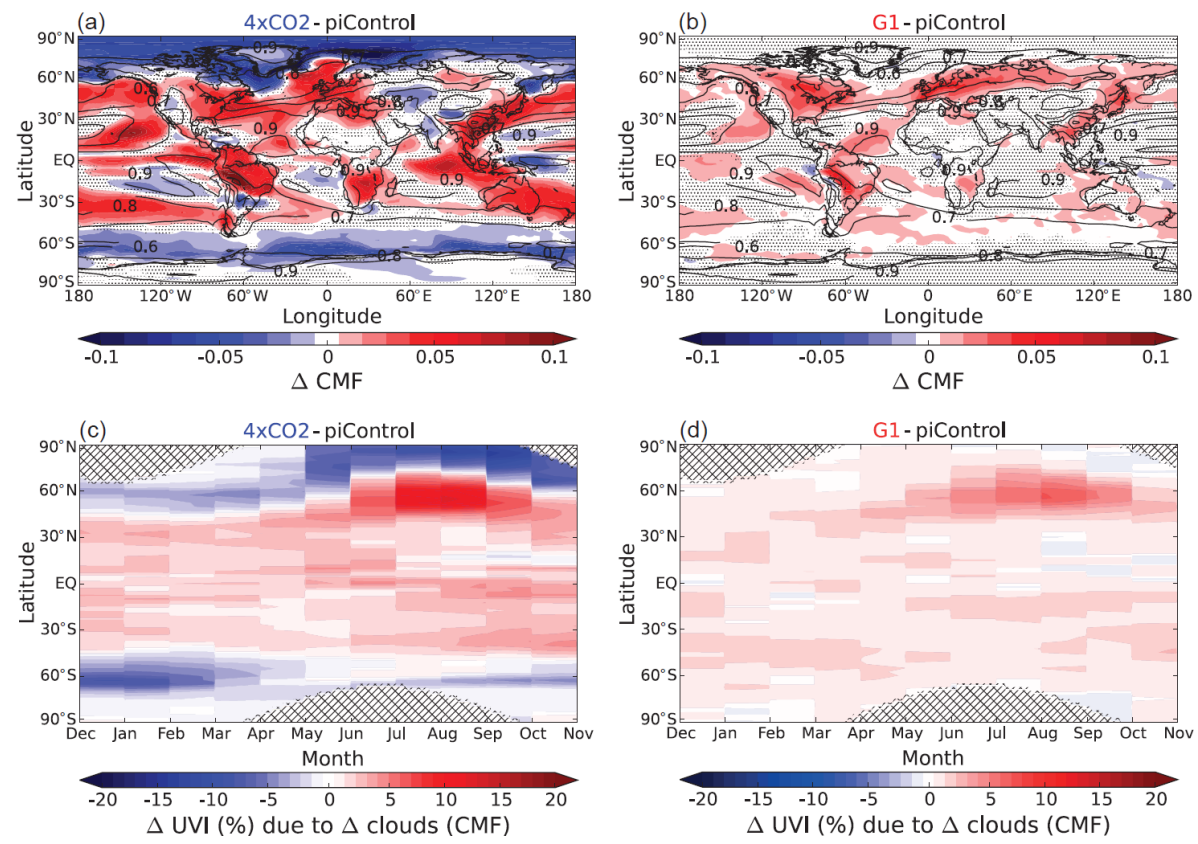

Figure 5. Differences in the cloud modification factor and their impact on the UV index. (a) Annual mean $\Delta \mathrm{CMF}^{(\mathrm{colours})}$ under $4 \times \mathrm{CO}_{2}$ and (b) under G1 relative to piControl (contour lines). Non-significant changes (using a two-tailed Student's $t$ test at the $95 \%$ confidence level) are marked by stippling. Zonal mean percentage changes in the UV index at noon induced by $\Delta \mathrm{CMF}$ are shown for $(\mathbf{c}) 4 \times \mathrm{CO}_{2}$ and (d) G1 according to the formulas by den Outer et al. (2005) and Staiger et al. (2008). Polar night regions in (c, d) are crossed out; both daily (solar declination) and monthly changes (ozone) are considered, giving rise to a less smooth appearance.

Net: $\mathrm{O}_{3}+\mathrm{H}_{2} \mathrm{O}+h v \rightarrow \mathrm{O}_{2}+2 \mathrm{OH}$

is of prime importance. This reaction pathway is nonlinearly dependent on stratospheric ozone changes due to the photons needed in Reaction (R3) (McKenzie et al., 2011).

ii. Changes in tropospheric concentrations of chemical species involved in the formation of ozone or its depletion, for example due to changes in atmospheric humidity and thus in concentrations of a key reactant in loss reactions such as Reaction (R5).

iii. Changes in stratosphere-troposphere exchange (STE) (Holton et al., 1995; Lin et al., 2014, 2015; Morgenstern et al., 2009; Neu et al., 2014; Zeng et al., 2010), i.e. due to changes in the transport of ozone from the ozonerich stratosphere into the troposphere. Such changes are strongly coupled to changes in atmospheric dynamics.

In our simulations, there is a global mean surface ozone increase in $\mathrm{G} 1(+5.0 \%)$ and a decrease in $4 \times \mathrm{CO}_{2}(-4.2 \%)$, see Table 2. The surface ozone differences between the runs are to first order determined by processes i and ii. Firstly, UV fluxes into the troposphere decrease in G1 due both to the solar irradiance reduction and the increase in stratospheric ozone concentrations. The UV reduction in G1 relative to piControl leads to a $\sim 5-10 \%$ reduction in the flux through Reaction (R3) in the tropical troposphere (and $\sim 15 \%$ reduction at higher latitudes). These results contrast with the changes between $4 \times \mathrm{CO}_{2}$ and piControl where the reaction flux increases in the tropical troposphere by $\sim 15 \%$. It is clear that changes in the stratosphere under both increased greenhouse gases, or under SRM, would have important consequences for the UV fluxes into the troposphere and, hence, for surface irradiation and tropospheric chemistry. SRM does not avoid changes to the stratosphere (and hence to the troposphere) that increased $\mathrm{CO}_{2}$ would lead to.

Secondly, the tropospheric humidity changes under SRM contrast significantly with those found under $4 \times \mathrm{CO}_{2}$. In the latter case, tropospheric humidity increases while for G1 we find, in common with many other studies mentioned above, a weakening of the hydrological cycle and reduced specific humidity. In our calculations, tropospheric humidity is up to $20 \%$ lower in G1 under SRM than in piControl. Consequently, Reaction (R4) slows down by $\sim 10-20 \%$ in the lower-middle troposphere and by up to $\sim 25-30 \%$ in the upper troposphere in G1.

Changes in STE (iii) have a negligible effect on the global mean surface ozone change in G1 (Table 2). Nonetheless, STE can be regionally and seasonally important under $4 \times \mathrm{CO}_{2}$, where surface ozone increases at mid- and high latitudes in the Northern Hemisphere and Southern Hemisphere (Fig. 6a). These annual mean changes result from increases during the respective winter and spring seasons when STE increases (by $\sim 38 \%$ on the annual mean). 

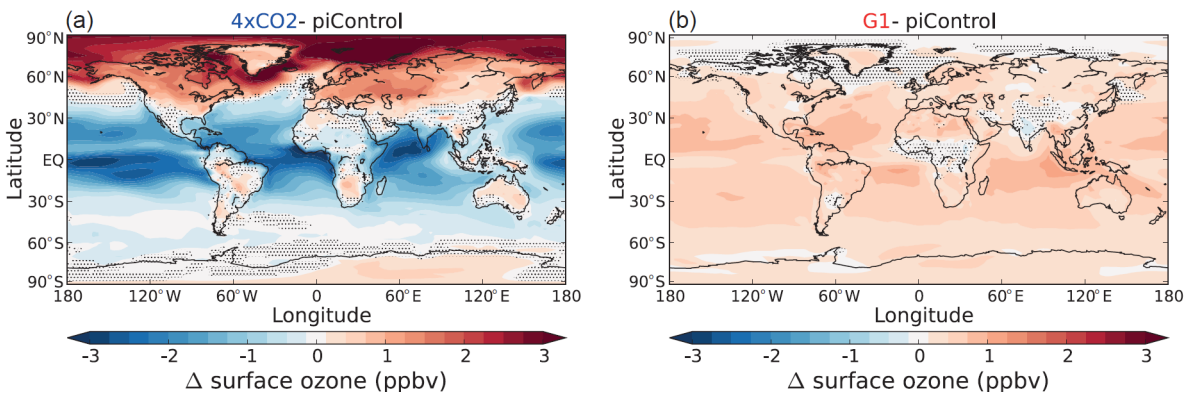

Figure 6. Annual mean surface ozone changes. Absolute values (ppbv). Difference between (a) $4 \times \mathrm{CO}_{2}$ and piControl, (b) $\mathrm{G} 1$ and piControl. Non-significant changes (using a two-tailed Student's $t$ test at the $95 \%$ confidence level) are marked by stippling.

We emphasize that the effect of SRM on tropospheric chemistry is expected to be strongly dependent on the scenario, reference state, and geoengineering method used. Here, we assume pre-industrial conditions by following the G1 scenario, which only allows for low, natural background pollution. Under different forcing scenarios other aspects of tropospheric chemistry could change the surface ozone response. For example, different chemical mechanisms could be more important for SRM under more polluted conditions (e.g. Morgenstern et al., 2013; Squire et al., 2014; Tang et al., 2011). Nevertheless, changes in humidity and photolysis as described here are robust modelling features that could occur under a range of geoengineering scenarios. These mechanisms will be key to tropospheric chemistry considerations under geoengineering in general. Consequently, our results demonstrate the potential for substantial changes in tropospheric chemistry in the different climate state created by SRM. Here, we find a particularly strong effect in the tropics, where model surface ozone increases under G1 and decreases under $4 \times \mathrm{CO}_{2}$, amounting to annual mean differences of around 5 ppbv between these two simulations in some regions, compare Fig. 6a and b. As with the surface ozone response under a range of RCP scenarios (which can differ in sign, O'Connor et al., 2014; Young et al., 2013), there is clearly a need to study surface ozone changes for a range of geoengineering forcing scenarios.

\section{Discussion and conclusions}

Using a coupled atmosphere-ocean chemistry-climate model, we have carried out an idealized SRM experiment in which we offset the effect of quadrupling atmospheric carbon dioxide on the global mean surface temperature by reducing the incoming solar radiation. Although the global mean surface temperature is, by design, unchanged in this geoengineering experiment, other environmental factors change considerably. In particular, we find large increases in stratospheric ozone, with an $\sim 8 \%$ increase in global mean column ozone. Solar radiation management under G1 fails to offset the cooling of the stratosphere resulting from increased $\mathrm{CO}_{2}$, which leads to higher ozone concentrations there. The reduction in solar flux intensity in G1 also plays a role in reducing ozone loss. In consequence, the stratospheric ozone optical depth increases and leads to a reduction in tropospheric UV, with regional and seasonal reductions of up to $\sim 20 \%$ in local UV-indices at the surface. This reduced surface UV could have adverse effects on medical conditions connected to vitamin D deficiency. In contrast, the general decrease in UV radiation is also expected to have beneficial effects such as a reduced likelihood in populations of developing skin cancer. We find that cloud-induced UV changes play a minor role compared with the change in ozone column.

A further unintended consequence of the SRM scheme considered here would be a change in tropospheric composition. The main drivers of change are decreases in tropospheric specific humidity as well as a reduced flux of UV$\mathrm{B}$ and UV-A radiation into the troposphere. Relative to the pre-industrial control run, surface ozone increases in G1 by about $5 \%$ (and decreases in $4 \times \mathrm{CO}_{2}$ ). Such an increase is qualitatively consistent with calculations, with detailed tropospheric chemistry schemes, of tropospheric ozone changes following an increase in stratospheric ozone (e.g. Banerjee et al., 2016). A major challenge in the 21 st century will be to prevent large changes in tropospheric ozone, which would follow increased emissions of $\mathrm{NO}_{x}$ and volatile organic compounds. It is important that geoengineering schemes do not make this challenge even more difficult. We note that the increase in ozone found here could also lead to a change in the lifetime of the greenhouse gas methane in a geoengineered climate (Holmes et al., 2013; Morgenstern et al., 2013) and thus in the amount of solar geoengineering needed to offset the anthropogenic greenhouse gas forcing.

It is important to stress again that our modelled changes in atmospheric composition are strongly scenario- and SRM scheme-dependent. Important factors in other scenarios that would affect composition include the reduction in ozonedepleting substances by the Montreal Protocol, not considered here, or more detailed changes in tropospheric ozone precursors (Squire et al., 2015; Young et al., 2013). For stratospheric particle injection schemes, stratospheric ozone depletion would be a major concern (e.g. Pope et al., 2012), 
especially in the near future. In addition, UV considerations for aerosol schemes are further complicated by UV scattering and absorption by the aerosol particles (Tilmes et al., 2012) as well as aerosol indirect effects (Kuebbeler et al., 2012). Aerosol geoengineering might also affect the stratospheric circulation (Ferraro et al., 2015) with likely changes in STE different than found here for the G1 experiment. Finally, it is also unclear how long-term injections of aerosols into the atmosphere would affect air quality at the surface due to potentially much increased particle pollution.

In conclusion, increases in $\mathrm{CO}_{2}$ will increase the stratospheric ozone column and solar radiation management schemes will not offset this increase. In the G1 experiment considered here, large increases in stratospheric ozone are calculated leading to decreases in tropospheric UV. That surface UV and surface ozone would change under solar geoengineering is a robust modelling result and their effects on human health and ecology could be considerable. Just as with continued ocean acidification (Caldeira and Wickett, 2003) and changes in the hydrological cycle under SRM, ozone changes and their effect on surface UV and air quality would have to be expected in a solar geoengineered world. Consequently, we highlight this issue as an important factor to be accounted for in future discussions and evaluations of all SRM methods.

Acknowledgements. We thank the European Research Council for funding through the ACCI project, project number 267760. In particular, we thank Jonathan M. Gregory (UK Met Office, University of Reading), Manoj M. Joshi (University of East Anglia) and Annette Osprey (University of Reading) for model development as part of the QUEST-ESM project supported by the UK Natural Environment Research Council (NERC) under contract numbers $\mathrm{RH} / \mathrm{H} 10 / 19$ and R8/H12/124. We acknowledge use of the MONSooN system, a collaborative facility supplied under the Joint Weather and Climate Research Programme, which is a strategic partnership between the UK Met Office and NERC. For plotting, we used Matplotlib, a 2-D graphics environment for the Python programming language developed by Hunter (2007). We are grateful for advice of P. Telford during the model development stage of this project and thank the UKCA team at the UK Met Office for help and support.

Edited by: J.-U. Grooß

\section{References}

Avnery, S., Mauzerall, D. L., Liu, J., and Horowitz, L. W.: Global crop yield reductions due to surface ozone exposure: 2. Year 2030 potential crop production losses and economic damage under two scenarios of $\mathrm{O}_{3}$ pollution, Atmos. Environ., 45, 2297-2309, doi:10.1016/j.atmosenv.2011.01.002, 2011.

Bais, A. F., Tourpali, K., Kazantzidis, A., Akiyoshi, H., Bekki, S., Braesicke, P., Chipperfield, M. P., Dameris, M., Eyring, V., Garny, H., Iachetti, D., Jöckel, P., Kubin, A., Langematz, U.,
Mancini, E., Michou, M., Morgenstern, O., Nakamura, T., Newman, P. A., Pitari, G., Plummer, D. A., Rozanov, E., Shepherd, T. G., Shibata, K., Tian, W., and Yamashita, Y.: Projections of UV radiation changes in the 21st century: Impact of ozone recovery and cloud effects, Atmos. Chem. Phys., 11, 7533-7545, doi:10.5194/acp-11-7533-2011, 2011.

Bais, A. F., McKenzie, R. L., Bernhard, G., Aucamp, P. J., Ilyas, M., Madronich, S., and Tourpali, K.: Ozone depletion and climate change: impacts on UV radiation, Photochem. Photobiol. Sci., 14, 19-52, doi:10.1039/C4PP90032D, 2015.

Bala, G., Duffy, P. B., and Taylor, K. E.: Impact of geoengineering schemes on the global hydrological cycle, P. Natl. Acad. Sci. USA, 105, 7664-7669, doi:10.1073/pnas.0711648105, 2008.

Banerjee, A., Maycock, A. C., Archibald, A. T., Abraham, N. L., Telford, P., Braesicke, P., and Pyle, J. A.: Drivers of changes in stratospheric and tropospheric ozone between year 2000 and 2100, Atmos. Chem. Phys., 16, 2727-2746, doi:10.5194/acp-16-2727-2016, 2016.

Bian, H. and Prather, M. J.: Fast-J2: Accurate simulation of stratospheric photolysis in global chemical models, J. Atmos. Chem., 41, 281-296, doi:10.1023/A:1014980619462, 2002.

Braesicke, P., Morgenstern, O. and Pyle, J.: Might dimming the sun change atmospheric ENSO teleconnections as we know them?, Atmos. Sci. Lett., 12, 184-188, doi:10.1002/asl.294, 2011.

Budyko, M. I.: Climatic changes, American Geophysical Union, Washington, D.C., 261 pp., 1977.

Caldeira, K. and Wickett, M. E.: Oceanography: Anthropogenic carbon and ocean pH, Nature, 425, 365, doi:10.1038/425365a, 2003.

Cicerone, R. J.: Geoengineering: Encouraging research and overseeing implementation, Climatic Change, 77, 221-226, doi:10.1007/s10584-006-9102-x, 2006.

Crutzen, P. J.: Albedo enhancement by stratospheric sulfur injections: A contribution to resolve a policy dilemma?, Climatic Change, 77, 211-219, doi:10.1007/s10584-006-9101-y, 2006.

Cusack, S.: Investigating $k$ distribution methods for parameterizing gaseous absorption in the Hadley Centre Climate Model, J. Geophys. Res., 104, 2051-2057, 1999.

den Outer, P. N., Slaper, H., and Tax, R. B.: UV radiation in the Netherlands: Assessing long-term variability and trends in relation to ozone and clouds, J. Geophys. Res.-Atmos., 110, D02203, doi:10.1029/2004JD004824, 2005.

Early, J. T.: Space-based solar shield to offset greenhouse effect, J. Br. Interplanet. Soc., 42, 567-569, 1989.

Edwards, J. M. and Slingo, A.: Studies with a flexible new radiation code. I: Choosing a comnfiguration for a largescale model, Q. J. Roy. Meteorol. Soc., 122, 689-719, doi:10.1002/qj.49712253107, 1996.

Fels, S. B., Mahlman, J. D., Schwarzkopf, M. D., and Sinclair, R. W.: Stratospheric Sensitivity to Perturbations in Ozone and Carbon Dioxide: Radiative and Dynamical Response, J. Atmos. Sci., 37, 2265-2297, doi:10.1175/15200469(1980)037<2265:SSTPIO>2.0.CO;2, 1980.

Ferraro, A. J., Charlton-Perez, A. J., and Highwood, E. J.: Stratospheric dynamics and midlatitude jets under geoengineering with space mirrors and sulfate and titania aerosols, J. Geophys. Res.Atmos., 120, 414-429, doi:10.1002/2014JD022734, 2015.

Fioletov, V. E., McArthur, L. J. B., Mathews, T. W., and Marrett, L.: On the relationship between erythemal and vitamin D action 
spectrum weighted ultraviolet radiation, J. Photochem. Photobiol. B, 95, 9-16, doi:10.1016/j.jphotobiol.2008.11.014, 2009.

Govindasamy, B. and Caldeira, K.: Geoengineering Earth's radiation balance to mitigate $\mathrm{CO}_{2}$ induced climate change, Geophys. Res. Lett., 27, 2141-2144, doi:10.1029/1999GL006086, 2000.

Govindasamy, B., Thompson, S., Duffy, P. B., Caldeira, K., and Delire, C.: Impact of geoengineering schemes on the terrestrial biosphere, Geophys. Res. Lett., 29, 2061, doi:10.1029/2002GL015911, 2002.

Govindasamy, B., Caldeira, K., and Duffy, P. B.: Geoengineering Earth's radiation balance to mitigate climate change from a quadrupling of $\mathrm{CO}_{2}$, Global Planet. Change, 37, 157-168, doi:10.1016/S0921-8181(02)00195-9, 2003.

Haigh, J. D. and Pyle, J. A.: Ozone perturbation experiments in a two-dimensional circulation model, Q. J. Roy. Meteorol. Soc., 108, 551-574, doi:10.1002/qj.49710845705, 1982.

Heckendorn, P., Weisenstein, D., Fueglistaler, S., Luo, B. P., Rozanov, E., Schraner, M., Thomason, L. W., and Peter, T.: The Impact of Geoengineering Aerosols on Stratospheric Temperature and Ozone, Environ. Res. Lett., 4, 045108, doi:10.1088/1748-9326/4/4/045108, 2011.

Hewitt, H. T., Copsey, D., Culverwell, I. D., Harris, C. M., Hill, R. S. R., Keen, A. B., McLaren, A. J., and Hunke, E. C.: Design and implementation of the infrastructure of HadGEM3: The next-generation Met Office climate modelling system, Geosci. Model Dev., 4, 223-253, doi:10.5194/gmd-4-223-2011, 2011.

Holick, M. F.: The Cutaneous Photosynthesis of Previtamin D3: A Unique Photoendocrine System, J. Invest. Dermatol., 77, 51-58, doi:10.1111/1523-1747.ep12479237, 1981.

Holmes, C. D., Prather, M. J., Søvde, O. A., and Myhre, G.: Future methane, hydroxyl, and their uncertainties: Key climate and emission parameters for future predictions, Atmos. Chem. Phys., 13, 285-302, doi:10.5194/acp-13-285-2013, 2013.

Holton, J. R., Haynes, P. H., McIntyre, M. E., Douglass, A. R., Rood, R. B., and Pfister, L.: Stratosphere-Troposphere Exchange, Rev. Geophys., 33, 403-439, doi:10.1029/95RG02097, 1995.

Hunke, E. C. and Lipscomb, W. H.: the Los Alamos sea ice model documentation and software user's manual, Version 4.0, LACC-06-012, Los Alamos National Laboratory, Los Alamos, NM, 2008.

Hunter, J. D.: Matplotlib: A 2D graphics environment, Comput. Sci. Eng., 9, 90-95, 2007.

Jackman, C. H. and Fleming, E. L.: Stratospheric ozone response to a solar irradiance reduction in a quadrupled $\mathrm{CO}_{2}$ environment, Earth's Futur., 2, 331-340, doi:10.1002/2014EF000244, 2014.

Jones, A., Haywood, J., and Boucher, O.: A comparison of the climate impacts of geoengineering by stratospheric $\mathrm{SO} 2$ injection and by brightening of marine stratocumulus cloud, Atmos. Sci. Lett., 12, 176-183, doi:10.1002/as1.291, 2011.

Jonsson, A. I., de Grandpré, J., Fomichev, V. I., McConnell, J. C., and Beagley, S. R.: Doubled $\mathrm{CO}_{2}$-induced cooling in the middle atmosphere: Photochemical analysis of the ozone radiative feedback, J. Geophys. Res.-Atmos., 109, D24103, doi:10.1029/2004JD005093, 2004.

Keith, D. W.: Geoengineering the Climate: History and Prospect, Annu. Rev. Energy Environ., 25, 245-284, doi:10.1146/annurev.energy.25.1.245, 2000.

Kravitz, B., Robock, A., Boucher, O., Schmidt, H., Taylor, K. E., Stenchikov, G., and Schulz, M.: The Geoengineering Model In- tercomparison Project (GeoMIP), Atmos. Sci. Lett., 12, 162 167, doi:10.1002/asl.316, 2011.

Kravitz, B., Robock, A., Shindell, D. T., and Miller, M. A.: Sensitivity of stratospheric geoengineering with black carbon to aerosol size and altitude of injection, J. Geophys. Res., 117, D09203, doi:10.1029/2011JD017341, 2012.

Kravitz, B., Robock, A., Forster, P. M., Haywood, J. M., Lawrence, M. G., and Schmidt, H.: An overview of the Geoengineering Model Intercomparison Project (GeoMIP), J. Geophys. Res.Atmos., 118, 13103-13107, doi:10.1002/2013JD020569, 2013a.

Kravitz, B., Caldeira, K., Boucher, O., Robock, A., Rasch, P. J., Alterskjær, K., Karam, D. B., Cole, J. N. S., Curry, C. L., Haywood, J. M., Irvine, P. J., Ji, D., Jones, A., Kristjánsson, J. E., Lunt, D. J., Moore, J. C., Niemeier, U., Schmidt, H., Schulz, M., Singh, B., Tilmes, S., Watanabe, S., Yang, S., and Yoon, J. H.: Climate model response from the Geoengineering Model Intercomparison Project (GeoMIP), J. Geophys. Res.-Atmos., 118, 8320-8332, doi:10.1002/jgrd.50646, 2013b.

Kuebbeler, M., Lohmann, U., and Feichter, J.: Effects of stratospheric sulfate aerosol geo-engineering on cirrus clouds, Geophys. Res. Lett., 39, L23803, doi:10.1029/2012GL053797, 2012.

Lin, M., Horowitz, L. W., Oltmans, S. J., Fiore, A. M., and Fan, S.: Tropospheric ozone trends at Mauna Loa Observatory tied to decadal climate variability, Nat. Geosci., 7, 136-143, doi:10.1038/ngeo2066, 2014.

Lin, M., Fiore, A. M., Horowitz, L. W., Langford, A. O., Oltmans, S. J., Tarasick, D., and Rieder, H. E.: Climate variability modulates western US ozone air quality in spring via deep stratospheric intrusions, Nat. Commun., 6, 7105, doi:10.1038/ncomms8105, 2015.

Lunt, D. J., Ridgwell, A., Valdes, P. J., and Seale, A.: Sunshade World: A fully coupled GCM evaluation of the climatic impacts of geoengineering, Geophys. Res. Lett., 35, L12710, doi:10.1029/2008GL033674, 2008 .

Madec, G., Delecluse, P., Imbard, M. and Levy, C.: OPA 8.1 ocean general circulation model - reference manual, Note du Pole de modélisation, Institut Pierre-Simon Laplace (IPSL), France, 1998.

Madronich, S.: Analytic formula for the clear-sky UV index, Photochem. Photobiol., 83, 1537-1538, doi:10.1111/j.17511097.2007.00200.x, 2007.

Madronich, S., Shao, M., Wilson, S. R., Solomon, K. R., Longstreth, J. D., and Tang, X. Y.: Changes in air quality and tropospheric composition due to depletion of stratospheric ozone and interactions with changing climate: implications for human and environmental health, Photochem. Photobiol. Sci., 14, 149169, doi:10.1039/C4PP90037E, 2015.

Matthews, H. D. and Caldeira, K.: Transient climate-carbon simulations of planetary geoengineering, P. Natl. Acad. Sci. USA, 104 9949-9954, doi:10.1073/pnas.0700419104, 2007.

Maycock, A. C., Shine, K. P., and Joshi, M. M.: The temperature response to stratospheric water vapour changes, Q. J. Roy. Meteorol. Soc., 137, 1070-1082, doi:10.1002/qj.822, 2011.

McKenzie, R. L., Liley, J. B., and Björn, L. O.: UV radiation: Balancing risks and benefits, Photochem. Photobiol., 85, 88-98, doi:10.1111/j.1751-1097.2008.00400.x, 2009.

McKenzie, R. L., Aucamp, P. J., Bais, A. F., Björn, L. O., Ilyas, M., and Madronich, S.: Ozone depletion and climate change: im- 
pacts on UV radiation, Photochem. Photobiol. Sci., 10, 182-198, doi:10.1039/c0pp90034f, 2011.

Moore, J. C., Rinke, A., Yu, X., Ji, D., Cui, X., Li, Y., Alterskjær, K., Kristjánsson, J. E., Muri, H., Boucher, O., Huneeus, N., Kravitz, B., Robock, A., Niemeier, U., Schulz, M., Tilmes, S., Watanabe, S., and Yang, S.: Arctic sea ice and atmospheric circulation under the GeoMIP G1 scenario, J. Geophys. Res.-Atmos., 119, 567583, doi:10.1002/2013JD021060, 2014.

Mora, J. R., Iwata, M., and von Andrian, U. H.: Vitamin effects on the immune system: vitamins $\mathrm{A}$ and $\mathrm{D}$ take centre stage, Nat. Rev. Immunol., 8, 685-698, doi:10.1038/nri2378, 2008.

Morgenstern, O., Braesicke, P., O'Connor, F. M., Bushell, A. C., Johnson, C. E., Osprey, S. M., and Pyle, J. A.: Evaluation of the new UKCA climate-composition model - Part 1: The stratosphere, Geosci. Model Dev., 2, 43-57, doi:10.5194/gmd-2-432009, 2009.

Morgenstern, O., Zeng, G., Abraham, N. L., Telford, P. J., Braesicke, P., Pyle, J. A., Hardiman, S. C., O'Connor, F. M., and Johnson, C. E.: Impacts of climate change, ozone recovery, and increasing methane on surface ozone and the tropospheric oxidizing capacity, J. Geophys. Res.-Atmos., 118, 1028-1041, doi:10.1029/2012JD018382, 2013.

Moss, R. H., Edmonds, J. A., Hibbard, K. A., Manning, M. R., Rose, S. K., van Vuuren, D. P., Carter, T. R., Emori, S., Kainuma, M., Kram, T., Meehl, G. A., Mitchell, J. F. B., Nakicenovic, N., Riahi, K., Smith, S. J., Stouffer, R. J., Thomson, A. M., Weyant, J. P., and Wilbanks, T. J.: The next generation of scenarios for climate change research and assessment, Nature, 463, 747-756, doi:10.1038/nature08823, 2010.

Neu, J. L., Prather, M. J., and Penner, J. E.: Global atmospheric chemistry: Integrating over fractional cloud cover, J. Geophys. Res.-Atmos., 112, D11306, doi:10.1029/2006JD008007, 2007.

Neu, J. L., Flury, T., Manney, G. L., Santee, M. L., Livesey, N. J., and Worden, J.: Tropospheric ozone variations governed by changes in stratospheric circulation, Nat. Geosci., 7, 340-344, doi:10.1038/NGEO2138, 2014.

Niemeier, U., Schmidt, H., Alterskjær, K., and Kristjánsson, J. E.: Solar irradiance reduction via climate engineering: Impact of different techniques on the energy balance and the hydrological cycle, J. Geophys. Res.-Atmos., 118, 11905-11917, doi:10.1002/2013JD020445, 2013.

Norval, M., Lucas, R. M., Cullen, A. P., de Gruijl, F. R., Longstreth, J., Takizawa, Y., and van der Leun, J. C.: The human health effects of ozone depletion and interactions with climate change, Photochem. Photobiol. Sci., 10, 199-225, doi:10.1039/C0PP90044C, 2011.

Nowack, P. J., Abraham, N. L., Maycock, A. C., Braesicke, P., Gregory, J. M., Joshi, M. M., Osprey, A., and Pyle, J. A.: A large ozone-circulation feedback and its implications for global warming assessments, Nat. Clim. Change, 5, 41-45, doi:10.1038/nclimate2451, 2015.

O'Connor, F. M., Johnson, C. E., Morgenstern, O., Abraham, N. L., Braesicke, P., Dalvi, M., Folberth, G. A., Sanderson, M. G., Telford, P. J., Voulgarakis, A., Young, P. J., Zeng, G., Collins, W. J., and Pyle, J. A.: Evaluation of the new UKCA climatecomposition model - Part 2: The Troposphere, Geosci. Model Dev., 7, 41-91, doi:10.5194/gmd-7-41-2014, 2014.

Oman, L. D., Waugh, D. W., Kawa, S. R., Stolarski, R. S., Douglass, A. R., and Newman, P. A.: Mechanisms and feedback causing changes in upper stratospheric ozone in the 21st century, J. Geophys. Res.-Atmos., 115, D24306, doi:10.1029/2009JD012397, 2010.

Pitari, G., Aquila, V., Kravitz, B., Robock, A., Watanabe, S., Cionni, I., de Luca, N., di Genova, G., Mancini, E., and Tilmes, S.: Stratospheric ozone response to sulfate geoengineering: Results from the Geoengineering Model Intercomparison Project (GeoMIP), J. Geophys. Res.-Atmos., 119, 2629-2653, doi:10.1002/2013JD020566, 2014.

Pope, F. D., Braesicke, P., Grainger, R. G., Kalberer, M., Watson, I. M., Davidson, P. J., and Cox, R. A.: Stratospheric aerosol particles and solar-radiation management, Nat. Clim. Change, 2, 713719, doi:10.1038/nclimate1528, 2012.

Portmann, R. W. and Solomon, S.: Indirect radiative forcing of the ozone layer during the 21 st century, Geophys. Res. Lett., 34, L02813, doi:10.1029/2006GL028252, 2007.

Price, C. and Rind, D.: A simple lightning parameterization for calculating global lightning distributions, J. Geophys. Res.-Atmos., 97, 9919-9933, doi:10.1029/92JD00719, 1992.

Price, C. and Rind, D.: Modeling Global Lightning Distributions in a General Circulation Model, Mon Weather Rev., 122, 1930-1939, doi:10.1175/15200493(1994)122<1930:MGLDIA>2.0.CO;2, 1994.

Rasch, P. J., Tilmes, S., Turco, R. P., Robock, A., Oman, L., Chen, C.-C., Stenchikov, G. L., and Garcia, R. R.: An overview of geoengineering of climate using stratospheric sulphate aerosols, Philos. Trans. A, 366, 4007-4037, doi:10.1098/rsta.2008.0131, 2008.

Revell, L. E., Bodeker, G. E., Smale, D., Lehmann, R., Huck, P. E., Williamson, B. E., Rozanov, E., and Struthers, H.: The effectiveness of $\mathrm{N}_{2} \mathrm{O}$ in depleting stratospheric ozone, Geophys. Res. Lett., 39, L15806, doi:10.1029/2012GL052143, 2012.

Ricke, K. L., Morgan, M. G., and Allen, M. R.: Regional climate response to solar-radiation management, Nat. Geosci., 3, 537541, doi:10.1038/ngeo915, 2010.

Robock, A., Oman, L., and Stenchikov, G. L.: Regional climate responses to geoengineering with tropical and Arctic SO2 injections, J. Geophys. Res.-Atmos., 113, D16101, doi:10.1029/2008JD010050, 2008.

Ross, A. C., Taylor, C. L., Yaktine, A. L., and Del Valle, H. B.: Institute of Medicine (US): Dietary reference intakes for calcium and vitamin D, National Academies Press, Washington, D.C., USA, 2011.

Schmidt, H., Alterskjær, K., Bou Karam, D., Boucher, O., Jones, A., Kristjánsson, J. E., Niemeier, U., Schulz, M., Aaheim, A., Benduhn, F., Lawrence, M., and Timmreck, C.: Solar irradiance reduction to counteract radiative forcing from a quadrupling of $\mathrm{CO}_{2}$ : climate responses simulated by four earth system models, Earth Syst. Dynam., 3, 63-78, doi:10.5194/esd-3-63-2012, 2012.

Seifritz, W.: Mirrors to halt global warming?, Nature, 340, 603, doi:10.1038/340603a0, 1989.

Shepherd, J. G.: Geoengineering the climate: science, governance and uncertainty, Royal Society, London, UK, 2009.

Shepherd, T. G. and McLandress, C.: A Robust Mechanism for Strengthening of the Brewer-Dobson Circulation in Response to Climate Change: Critical-Layer Control of Subtropical Wave Breaking, J. Atmos. Sci., 68, 784-797, doi:10.1175/2010JAS3608.1, 2011. 
Silva, R. A., West, J. J., Zhang, Y., Anenberg, S. C., Lamarque, J.F., Shindell, D. T., Collins, W. J., Dalsoren, S., Faluvegi, G., Folberth, G., Horowitz, L. W., Nagashima, T., Naik, V., Rumbold, S., Skeie, R., Sudo, K., Takemura, T., Bergmann, D., CameronSmith, P., Cionni, I., Doherty, R. M., Eyring, V., Josse, B., MacKenzie, I. A., Plummer, D., Righi, M., Stevenson, D. S., Strode, S., Szopa, S., and Zeng, G.: Global premature mortality due to anthropogenic outdoor air pollution and the contribution of past climate change, Environ. Res. Lett., 8, 034005, doi:10.1088/1748-9326/8/3/034005, 2013.

Slaper, H., Velders, G. J. M., Daniel, J. S., de Gruijl, F. R., and van der Leun, J. C.: Estimates of ozone depletion and skin cancer incidence to examine the Vienna Convention achievements, Nature, 384, 256-258, doi:10.1038/384256a0, 1996.

Squire, O. J., Archibald, A. T., Abraham, N. L., Beerling, D. J., Hewitt, C. N., Lathière, J., Pike, R. C., Telford, P. J., and Pyle, J. A.: Influence of future climate and cropland expansion on isoprene emissions and tropospheric ozone, Atmos. Chem. Phys., 14, 1011-1024, doi:10.5194/acp-14-1011-2014, 2014.

Squire, O. J., Archibald, A. T., Griffiths, P. T., Jenkin, M. E., Smith, D., and Pyle, J. A.: Influence of isoprene chemical mechanism on modelled changes in tropospheric ozone due to climate and land use over the 21st century, Atmos. Chem. Phys., 15, 5123-5143, doi:10.5194/acp-15-5123-2015, 2015.

Staiger, H., den Outer, P. N., Bais, A. F., Feister, U., Johnsen, B., and Vuilleumier, L.: Hourly resolved cloud modification factors in the ultraviolet, Atmos. Chem. Phys., 8, 2493-2508, doi:10.5194/acp-8-2493-2008, 2008.

Stocker, T. F., Qin, D., Plattner, G. K., Tignor, M., Allen, S. K., Boschung, J., Nauels, A., Xia, Y., Bex, B., and Midgley, B. M.: IPCC, 2013: Climate Change 2013: the Physical Science Basis. Contribution of working group I to the Fifth Assessment Report of the Intergovernmental Panel on Climate Change, Geneva, Switzerland, 2013.

Tang, X., Wilson, S. R., Solomon, K. R., Shao, M., and Madronich, S.: Changes in air quality and tropospheric composition due to depletion of stratospheric ozone and interactions with climate, Photochem. Photobiol. Sci., 10, 280-291, doi:10.1039/c0pp90039g, 2011.

Taylor, K. E., Stouffer, R. J., and Meehl, G. A.: An overview of CMIP5 and the experiment design, B. Am. Meteorol. Soc., 93, 485-498, doi:10.1175/BAMS-D-11-00094.1, 2012.

Telford, P. J., Abraham, N. L., Archibald, A. T., Braesicke, P., Dalvi, M., Morgenstern, O., O'Connor, F. M., Richards, N. A. D., and Pyle, J. A.: Implementation of the Fast-JX Photolysis scheme (v6.4) into the UKCA component of the MetUM chemistry-climate model (v7.3), Geosci. Model Dev., 6, 161177, doi:10.5194/gmd-6-161-2013, 2013.

Tilmes, S., Müller, R., and Salawitch, R.: The Sensitivity of Polar Ozone Depletion to Proposed Geoengineering Schemes, Science, 80, 320, 1201-1204, doi:10.1126/science.1153966, 2008.
Tilmes, S., Garcia, R. R., Kinnison, D. E., Gettelman, A., and Rasch, P. J.: Impact of geoengineered aerosols on the troposphere and stratosphere, J. Geophys. Res.-Atmos., 114, D12305, doi:10.1029/2008JD011420, 2009.

Tilmes, S., Kinnison, D. E., Garcia, R. R., Salawitch, R., Canty, T., Lee-Taylor, J., Madronich, S., and Chance, K.: Impact of very short-lived halogens on stratospheric ozone abundance and UV radiation in a geo-engineered atmosphere, Atmos. Chem. Phys., 12, 10945-10955, doi:10.5194/acp-12-10945-2012, 2012.

Tilmes, S., Fasullo, J., Lamarque, J. F., Marsh, D. R., Mills, M., Alterskjær, K., Muri, H., Kristjánsson, J. E., Boucher, O., Schulz, M., Cole, J. N. S., Curry, C. L., Jones, A., Haywood, J., Irvine, P. J., Ji, D., Moore, J. C., Karam, D. B., Kravitz, B., Rasch, P. J., Singh, B., Yoon, J. H., Niemeier, U., Schmidt, H., Robock, A., Yang, S., and Watanabe, S.: The hydrological impact of geoengineering in the Geoengineering Model Intercomparison Project (GeoMIP), J. Geophys. Res.-Atmos., 118, 11036-11058, doi:10.1002/jgrd.50868, 2013.

Weisenstein, D. K., Keith, D. W., and Dykema, J. A.: Solar geoengineering using solid aerosol in the stratosphere, Atmos. Chem. Phys., 15, 11835-11859, doi:10.5194/acp-15-11835-2015, 2015.

WHO - World Health Organization: Global Solar UV Index, Publication WHO/SDE/OEH/02.2, Geneva, Switzerland, 2002.

Wild, O., Zhu, X., and Prather, M. J.: Fast-J: Accurate simulation of in- and below-cloud photolysis in tropospheric chemical models, J. Atmos. Chem., 37, 245-282, doi:10.1023/A:1006415919030, 2000 .

Williamson, C. E., Zepp, R. G., Lucas, R. M., Madronich, S., Austin, A. T., Ballare, C. L., Norval, M., Sulzberger, B., Bais, A. F., McKenzie, R. L., Robinson, S. A., Hader, D.P., Paul, N. D., and Bornman, J. F.: Solar ultraviolet radiation in a changing climate, Nat. Clim. Change, 4, 434-441, doi:10.1038/NCLIMATE2225, 2014.

Young, P. J., Archibald, A. T., Bowman, K. W., Lamarque, J.-F., Naik, V., Stevenson, D. S., Tilmes, S., Voulgarakis, A., Wild, O., Bergmann, D., Cameron-Smith, P., Cionni, I., Collins, W. J., Dalsøren, S. B., Doherty, R. M., Eyring, V., Faluvegi, G., Horowitz, L. W., Josse, B., Lee, Y. H., MacKenzie, I. A., Nagashima, T., Plummer, D. A., Righi, M., Rumbold, S. T., Skeie, R. B., Shindell, D. T., Strode, S. A., Sudo, K., Szopa, S., and Zeng, G.: Preindustrial to end 21 st century projections of tropospheric ozone from the Atmospheric Chemistry and Climate Model Intercomparison Project (ACCMIP), Atmos. Chem. Phys., 13, 20632090, doi:10.5194/acp-13-2063-2013, 2013.

Zeng, G., Morgenstern, O., Braesicke, P., and Pyle, J. A.: Impact of stratospheric ozone recovery on tropospheric ozone and its budget, Geophys. Res. Lett., 37, L09805, doi:10.1029/2010GL042812, 2010. 